\title{
Phytoremediation Potential of Some Macrophytes from a Car Wash Stream in Buea, South Western Cameroon
}

\author{
Neculina Anyinkeng ${ }^{1 *}$, Godlove A. Neba1, Afui M. Mih"1\#, Aaron S. Tening² \\ ${ }^{1}$ Department of Botany and Plant Physiology, Faculty of Science, University of Buea, Buea, Cameroon \\ ${ }^{2}$ Department of Agronomic and Applied Molecular Sciences, Faculty of Agriculture and Veterinary Medicine, University of Buea, \\ Buea, Cameroon \\ Email: *anyinkengnicoline@yahoo.com
}

How to cite this paper: Anyinkeng, N., Neba, G.A., Mih, A.M. and Tening, A.S. (2020) Phytoremediation Potential of Some Macrophytes from a Car Wash Stream in Buea, South Western Cameroon. Journal of Environmental Protection, 11, 1052-1063. https://doi.org/10.4236/jep.2020.1112066

Received: November 21, 2020

Accepted: December 25, 2020

Published: December 28, 2020

Copyright $\odot 2020$ by author(s) and Scientific Research Publishing Inc. This work is licensed under the Creative Commons Attribution International License (CC BY 4.0).

http://creativecommons.org/licenses/by/4.0/

(c) (i) Open Access

\begin{abstract}
Phytoremediation is a cheap and environmentally friendly technique in which green plants in situ are used to clean the soil, sediments and water of heavy metals. This study investigated the phytoremediation potential of six naturally occurring macrophytes from Nange (a stream in Buea municipality where cars have been driven into and washed for over 20 years). Plant samples were collected before and after car wash, then analysed for copper, zinc, lead and cadmium accumulation. There was an increase in concentration of all the four heavy metals in water after carwash point, with $\mathrm{Zn}$ having the highest concentration $(0.27 \mathrm{mg} / \mathrm{L})$. Mean concentration of the heavy metals in the water showed that $\mathrm{Zn}$ and $\mathrm{Pb}$ had the highest concentrations $(0.24$ $\mathrm{mg} / \mathrm{L}$ each) while the least concentration was obtained in $\mathrm{Cu}(0.12 \mathrm{mg} / \mathrm{kg})$. Heavy metal concentrations in the sediments were higher after car wash point than before. Cadmium had the highest concentration $(5.58 \mathrm{mg} / \mathrm{kg})$ while $\mathrm{Cu}$ had the least $(0.75 \mathrm{mg} / \mathrm{kg})$. Ludwigia peruviana had the highest BAFs for all the heavy metals (22.95 for $\mathrm{Cu}, 33.41$ for $\mathrm{Zn}, 21.79$ for $\mathrm{Pb}$ and 7.85 for $\mathrm{Cd}$ ). Species with the leasts were: Anubias barteri for $\mathrm{Cu}$ (7.16), Polygonum persicaria for $\mathrm{Zn}$ (14.28), Rorippa nasturtium-aquaticum for $\mathrm{Pb}$ (11.60) and Vallisneria spiralis for $\mathrm{Cd}$ (1.98). L. peruviana had the highest $\mathrm{BAC}$ values $(\mathrm{Cu}=$ $10.11, \mathrm{Zn}=14.73, \mathrm{~Pb}=11.39, \mathrm{Cd}=3.85)$ and $\mathrm{BCF}$ values $(\mathrm{Cu}=12.84, \mathrm{Zn}=$ $18.67, \mathrm{~Pb}=10.40, \mathrm{Cd}=4.00)$. . . barteri had the highest $\mathrm{TF}(\mathrm{Cu}=1.49, \mathrm{Zn}=$ $1.27, \mathrm{Cd}=1.99)$ except for $\mathrm{Pb}$ where both $A$. barteri and $L$. peruviana each had a TF of 1.10. While all the six plants were found to be good accumulators of the heavy metals, $L$. peruviana showed remarkable efficiency indicating that the species is a good candidate for cleaning such environments.
\end{abstract}

\#This article is dedicated to the loving memory of Afui M. Mih who passed away before this article was published. 


\section{Keywords}

Phytoremediation, Macrophytes, Nange, Car Wash, Buea Municipality

\section{Introduction}

Macrophytes are larger plants which actively grow continuously or periodically depending on the availability of required amount of water. They occur as submerged, floating or emergent. The plants are very important in the structure and function of the aquatic system. However, their occurrence is threatened by factors including pollution [1]. Car wash is one major activity in streams that results to point pollution with pollutants such as oil, phosphorous, ammonia, surfactants, heavy metals and solid wastes reported from it [2]. Sources of heavy metals to aquatic environments include runoff from agricultural fields and urbanization, fertilizer application on nearby farms and gardens, waste disposal and car wash effluents [3].

Heavy metal pollution has harmful effects on biological systems due to the fact that the heavy metals do not undergo biodegradation and have long residence times. Toxic heavy metals such as $\mathrm{Pb}, \mathrm{Co}, \mathrm{Cd}$, and $\mathrm{Hg}$ can be differentiated from other pollutants in that they can be accumulated in living organisms, thus causing various diseases and disorders even in relatively lower concentrations [4] [5]. Heavy metals, with soil residence times of thousands of years, pose numerous health dangers to higher organisms. They are also known to have effect on plant growth, ground cover and negative impact on soil micro flora [6].

In most developing societies, water is a scarce resource and waste management remains a major constraint. Consequently, vehicle washing is a subject of water availability. This is the case of Buea where most vehicle washing is done directly in streams or their sides with effluents discharged directly into the streams.

Phytoremediation is a cheap and environmentally friendly technique in which green plants in situ are used to clean the soil, sediments and water of heavy metals. Plants with metal-accumulating capacity are known as accumulators with those accumulating $>1000 \mathrm{mgs} / \mathrm{kg}$ referred to as hyperaccumulators [7]. The US EPA [8] considers macrophytes to be "excellent indicators of watershed health" due to their remarkable response to environmental factors, ease of sampling and their ability to tolerate high concentrations of heavy metals [9]. Phytoremediation takes the advantage of the unique and selective uptake capabilities of plant root systems, together with the translocation, bioaccumulation, and contaminant degradation abilities of the entire plant body [10]. It has gained increasing attention as an emerging cheaper technology.

Studies on aquatic macrophytes, especially their ecology and bio-indication potential, have been on focus since the last two decades, with different plants demonstrating different accumulation potentials in different systems [7] [11]-[19]. 
Myriophyllum spicatum [20], Elodea canadensis, Lemna minor and Leptodictyum riparium [21] with Commelina benghalensis and Cynodon dactylon [22] are among the various species whose bioaccumulation potentials for heavy metals have been investigated in sediments and other polluted environments.

However, few of the studies on aquatic systems have included car wash [23] [24] [25]. In Cameroon, studies by [26] [27] and [28] focused on physico-chemical properties and phytoplankton diversity and abundance in streams under anthropogenic influences. This study investigated the heavy metal uptake potential of six macrophytes from Nange, a stream exposed to heavy metal pollution from agriculture and car wash in Buea municipality, southwest Cameroon in a bit to investigate their phytoremediation capabilities.

\section{Materials and Methods}

\subsection{Description of Study Site}

Buea is situated between latitudes $3^{\circ} 57^{\prime}$ and $4^{\circ} 27^{\prime} \mathrm{N}$, longitudes $8^{\circ} 58^{\prime}$ and $9^{\circ} 25^{\prime} \mathrm{E}$, and at an elevation of about $500-1500 \mathrm{~m}$ above sea level on the eastern flank of Mount Cameroon. It has a surface area of $870 \mathrm{~km}^{2}$ and is made up of 67 villages [29].

The Buea area is composed of undulating lands with rocks of different sizes and ages from volcanic eruptions. The natural vegetation is composed of lowland forest through montane forest and shrubs to savannah towards the peak of the mountain. The municipality is surrounded by an evergreen tropical ecosystem with very high biodiversity. The young soils are derived from pre-historic and historic lava flows and lapilli falls that covered the surface of the massive basaltic edifice, Mount Cameroon [30]. The fertile soils have encouraged agricultural activities with the establishment of both subsistence and plantation crop production farms. According to the 2005 national population census, the population of Buea was 11,325 inhabitants with an annual growth rate of $5.60 \%$ [31], resulting in a derived population of 226,458 inhabitants at the end of 2015.

The absence of conscious efforts to protect water catchments, haphazard waste disposal especially in water ways, deforestation (motivated by agriculture, timber for local consumption fuel wood, bark harvesting-Prunus) and bush fires have all contributed to degrade water sources in quantity and quality within the municipality.

Buea is a watershed area, characterized by many springs some of which develop into streams at lower elevation. Nange is a stream in Moli, a village within the municipality. It originates from the foot of the "Mami Water" hills and drains through gentle slope to the neighbouring Musaka village. The adjoining land to the stream is used for vegetable production especially in the dry season as well as sugarcane, banana and palm plantations. Upstream, cocoa production and subsistence farming dominate. The stream receives storm drains from these agricultural systems that make use of large quantities of agrochemicals including fertilizers and pesticides, some of which are applied through aerial sprays. In ad- 
dition, the stream has two carwash points at close proximity where cars are driven into the stream bed and washed alongside their engines (Figure 1). The stream has played this role for over 20 years with an increasing number of cars over the years. The average number of vehicles washed daily stood at 50 and 5 engines as of 2015. Other activities in the stream include bathing, laundry and subsistent fishing. Studies on the diversity and abundance of macrophytes in the stream revealed a total of 48 species, in 40 genera and 24 families, made up of submerged and emergent categories [32].

\subsection{Plant Sampling}

Macrophyte assessment was done using a $500 \mathrm{~m}$ long transect whose width was the entire span of the wetland including the stream itself [32]. The transect was laid out to cover points before and after the carwash points so as to capture the impact of point source pollution from the activity and also non-point source pollution on the stream and its biota. Following the inventory, five emergent plants species (Anubias barteri Schott., Commelina benghalensis L., Ludwigia peruviana (L.) H. Hara, Polygonum persicaria L., Rorippa nasturtium-aquaticum R. Br) and one submerged plant species (Vallisneria spiralis L.) were selected and sampled for heavy metal analysis. These species were observed to be amongst the most abundant macrophytes in the stream. Fresh whole samples of the species were collected in replicates of two, cleaned of debris, washed under slow running tap, then rinsed with distilled water. A. barteri and $L$. peruviana were each separated into root and shoot and packaged in envelopes, while $R$. nasturtium-aquaticum, V. spiralis, $P$. persicaria and $C$. benghalensis were packaged whole because of the fine nature of their roots. All the packaged samples were oven-dried at $65^{\circ} \mathrm{C}$ to constant weight, milled to fine powder using a blender, packaged in zip luck bags and sent for heavy metal analysis.

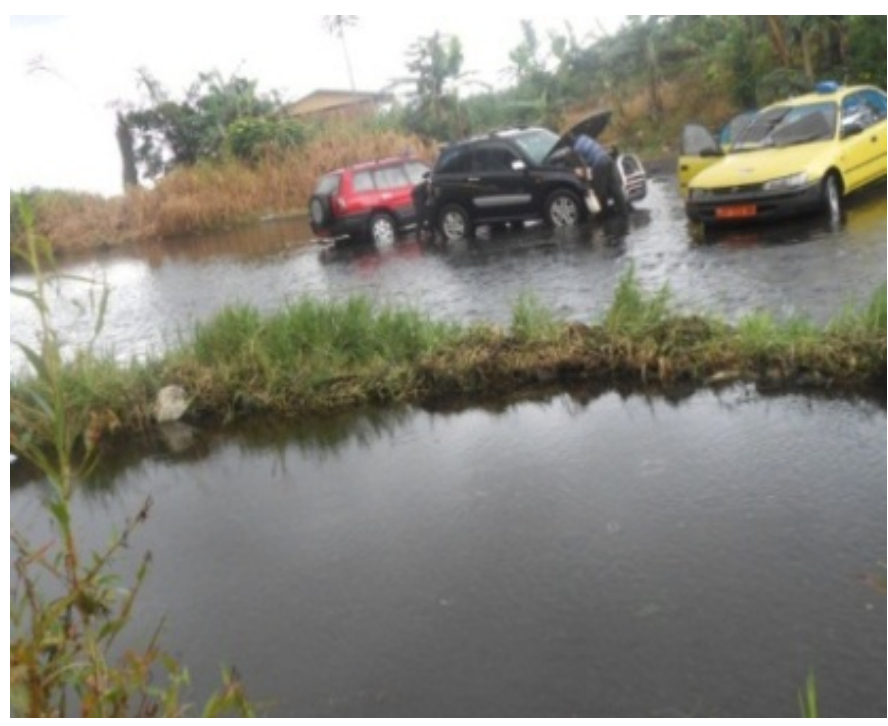

Figure 1. Car and engine washing in Nange, a stream within the Buea Municipality-Cameroon (Source: [27]). 


\subsection{Water and Sediment Sampling}

Two water samples were collected in $50 \mathrm{~mL}$ sterilized plastic bottles in duplicates at points before and after the carwash. Each sample constituted three random samples that were collected across the stream breadth then bulked and subsampled. All the samples were collected $5 \mathrm{~cm}$ below the surface. Upon collection, each sample was treated with two drops pure grade nitric acid and transported in ice buckets to the Life Sciences Laboratory of the University of Buea, packaged in black polythene bags and then stored below $4^{\circ} \mathrm{C}$ in a freezer (Asea Skandia AKF.370, Denmark) until analysis.

Sediment samples were similarly collected from the different water points using a plastic scooper. At each point, five random samples were collected. Samples were taken to the University of Buea Life Sciences Laboratory, air dried, sorted and sieved using $2 \mathrm{~mm}$ sieve, then bulked, homogenized and subsampled into zip luck bags for analysis.

\subsection{Sample Digestion and Analysis}

Sample digestion and analysis were carried out at the Soil and Environmental Chemistry Laboratory of the Faculty of Agronomy and Agricultural Sciences, University of Dschang, Cameroon.

Two millilitre of each water sample and two grams of each plant sample were digested with conc. nitric acid and HCL in the ratio 3:1 until transparent solutions were obtained. Twenty grams of each air-dried sediment sample was agitated for 30 minutes on stirring table in $100 \mathrm{~mL}$ of $0.5 \mathrm{M}$ nitric acid $\left(\mathrm{HNO}_{3}\right)$. The absorbances of $\mathrm{Cu}, \mathrm{Pb}, \mathrm{Zn}$ and $\mathrm{Cd}$ were determined in the filtrates using an atomic absorption spectrophotometer brand Rayleigh 130B series and the concentrations referred from standard curves.

Particle size for sediment samples was determined by the Bouyoucos hydrometer method, and $\mathrm{pH}$ using $\mathrm{pH}$ meter.

\subsection{Data Analysis}

All quantitative data were entered into Microsoft Office Excel 2010 and MINITAB 17 for generation of means and tables.

Bioaccumulation factors (BAF) of each plant for the various heavy metals were calculated using the equation:

$$
\mathrm{BAF}=\frac{[\text { metal }]_{\text {plant }}}{[\text { metal }]_{\text {sediment }}}
$$

For the two plant species that were separated into roots and shoots the following were further calculated: Bioaccumulation coefficient (BAC), Bio-concentration factor (BCF) and Translocation factor (TF)

$$
\mathrm{BAC}=\frac{[\mathrm{metal}]_{\text {shoot }}}{[\text { metal }]_{\text {sediment }}}
$$




$$
\begin{aligned}
\mathrm{BCF} & =\frac{[\text { metal }]_{\text {root }}}{[\text { metal }]_{\text {sediment }}} \\
\mathrm{TF} & =\frac{[\text { metal }]_{\text {shoot }}}{[\text { metal }]_{\text {root }}}
\end{aligned}
$$

\section{Results and Discussion}

\subsection{Heavy Metal Concentration in Water and Sediments}

The concentrations of the four heavy metals investigated in water and sediments are presented in Table 1. There was an increase in concentration of all the four heavy metals in water after car wash point, compared to before. Of all these, $\mathrm{Zn}$ had the highest concentration $(0.27 \mathrm{mg} / \mathrm{L})$ while $\mathrm{Cu}$ had the least $(0.13 \mathrm{mg} / \mathrm{L})$. The presence of these heavy metals in water is indicative of the fact that car wash effluents contribute to their discharge into the system [23]. [28] recorded high concentrations of $\mathrm{Cu}, \mathrm{Zn}$ and $\mathrm{Pb}$ on some surface waterbodies exposed to car wash facility influence within this same environment. The presence of heavy metals in water before car wash as was observed, could be attributed to inputs from other anthropogenic activities that are common along the stream banks [26] [27]. Mean concentration of the heavy metals in the water showed that $\mathrm{Zn}$ and $\mathrm{Pb}$ had the highest concentrations $(0.24 \mathrm{mg} / \mathrm{L}$ each) while the least concentration was obtained in $\mathrm{Cu}(0.12 \mathrm{mg} / \mathrm{kg})$.

It has been reported that copper may be present in wastewaters from a variety of chemical manufacturing processes employing copper salts or a copper catalyst in different range from $0.12 \mathrm{mg} / \mathrm{l}$ to $183 \mathrm{mg} / \mathrm{l}$ such as mining acid, mine drainage, paint and pigment manufacturing and motor vehicles [33]. $\mathrm{Zn}$ in car wash may come from metal working, surface treatments paint and varnish manufacturing, transport (brakes, wheels and asphalt) and galvanized surfaces. $\mathrm{Pb}$ can come from lead paints and car batteries while $\mathrm{Cd}$ could be attributed to the washing of Ni-Cd batteries, $\mathrm{Zn}$ containing materials as well as petroleum fuel used in cars. Also, Cd substances from the road dust attached to car surfaces and transferred to car wash points could be another source of input [25].

Heavy metal concentrations in the sediments were higher after car wash point than before. Cadmium had the highest concentration $(5.58 \mathrm{mg} / \mathrm{kg})$ while $\mathrm{Cu}$ had the least $(0.75 \mathrm{mg} / \mathrm{kg})$. Mean concentrations showed similar trend. Cadmium is

Table 1. Heavy metal concentrations in water and sediments from Nange-Buea.

\begin{tabular}{ccccccc}
\hline \multirow{2}{*}{ Heavy Metal } & \multicolumn{3}{c}{ Water $(\mathrm{mg} / \mathrm{L})$} & \multicolumn{3}{c}{ Sediment $(\mathrm{mg} / \mathrm{kg})$} \\
\cline { 2 - 7 } & Before & After & Mean & Before & After & Mean \\
\hline $\mathrm{Cu}$ & 0.10 & 0.13 & 0.12 & 0.48 & 0.75 & 0.61 \\
$\mathrm{Zn}$ & 0.22 & 0.27 & 0.24 & 0.84 & 1.18 & 1.01 \\
$\mathrm{~Pb}$ & 0.22 & 0.25 & 0.24 & 0.75 & 1.18 & 0.97 \\
$\mathrm{Cd}$ & 0.13 & 0.17 & 0.16 & 5.34 & 5.58 & 5.46 \\
\hline
\end{tabular}


relatively immobile in soil and sediments and as a surface derived contaminant, it accumulates in the surface layer. Here it poses a great risk to the ecosystem, as plant cadmium concentrations have been found to increase with increase in soil cadmium concentrations, this accumulation of cadmium may overtime increase the flow of cadmium through the food chain [34].

Generally, the concentrations of the heavy metals in the sediments were higher than in water suggesting their adsorption and accumulation unto these surfaces [12]. Exchanges between the sediments and the water column increase the rate of heavy metal migration, which is connected with the forms of occurrence in solid substrates and pore solutions in the sediments, as well as with physico-chemical conditions arising at the sediment/water boundary [35].

\subsection{Heavy Metal Concentrations in Plants}

There were variations in the uptake of the different heavy metals by different plants when assessed whole and in parts (Table 2). L. peruviana had the highest concentration of $\mathrm{Cu}(14.00 \mathrm{mg} / \mathrm{kg})$ while the least was obtained in $A$. barteri $(4.37 \mathrm{mg} / \mathrm{kg}) . \mathrm{Zn}$ had the highest concentration in $L$. peruviana $(33.74 \mathrm{mg} / \mathrm{kg})$ while the least was in $P$. persicaria $(14.43 \mathrm{mg} / \mathrm{kg}$ ). L. peruviana equally had the highest concentration of $\mathrm{Pb}(21.14 \mathrm{mg} / \mathrm{kg})$ and $\mathrm{Cd}(42.86 \mathrm{mg} / \mathrm{kg})$ while the least concentrations of these heavy metals were obtained in $R$. nasturtium-aquaticum $(11.25 \mathrm{mg} / \mathrm{kg})$ and $C$. benghalensis $(9.45 \mathrm{mg} / \mathrm{kg})$ respectively.

For the two species that were separated into parts, results indicated that $A$. barteri accumulated higher concentration of all the heavy metals at varied concentrations in the shoots than in the roots. In $L$. peruviana the trend was reversed, except for $\mathrm{Pb}$ where the shoot accumulated slightly more than the roots, an indication that the two species have different mechanisms of dealing with high concentrations of the heavy metals.

Table 2. Mean heavy metal concentration of six plants from Nange.

\begin{tabular}{cccccc}
\hline Species & Part & $\mathrm{Cu}(\mathrm{mg} / \mathrm{kg})$ & $\mathrm{Zn}(\mathrm{mg} / \mathrm{kg})$ & $\mathrm{Pb}(\mathrm{mg} / \mathrm{kg})$ & $\mathrm{Cd}(\mathrm{mg} / \mathrm{kg})$ \\
\hline C. benghalensis & Whole & 12.32 & 16.78 & 12.64 & 9.45 \\
$\begin{array}{c}\text { P. persicaria } \\
\text { R. nasturtium-aquaticum }\end{array}$ & Whole & 7.515 & 14.43 & 12.18 & 14.10 \\
V. spiralis & Whole & 12.54 & 17.88 & 11.25 & 16.94 \\
& Whole & 4.37 & 25.23 & 15.75 & 26.49 \\
A. barteri & Shoot & 2.62 & 14.09 & 8.25 & 17.62 \\
& Root & 1.75 & 11.14 & 7.5 & 8.87 \\
& Whole & 14 & 33.74 & 21.14 & 42.87 \\
& Shoot & 6.17 & 14.88 & 11.05 & 21.03 \\
& Root & 7.83 & 18.86 & 10.09 & 21.83 \\
\hline
\end{tabular}


The BAFs of the species varied with the different heavy metals (Table 3). $L$. peruviana had the highest BAFs for all the heavy metals ( 22.95 for $\mathrm{Cu}, 33.41$ for $\mathrm{Zn}, 21.79$ for $\mathrm{Pb}$ and 7.85 for $\mathrm{Cd}$ ) while different species had the leasts: $A$. barteri for $\mathrm{Cu}$ (7.16), $P$. persicaria for $\mathrm{Zn}$ (14.28), $R$. nasturtium-aquaticum for $\mathrm{Pb}$ (11.60) and V. spiralis for Cd (1.98).

Bioaccumulation factors (BAF) are used to determine the quantity of heavy metals absorbed by plants from the environment and to test for plants ability to serve as accumulators/phytoremediators. The higher the BAF values, the higher the risks pose to organisms along the food chain. BAF value $>2$ are regarded as high [36]. Results of this study recorded many very high BAF values, some 16 folds above 2, indicating the ability of the different species to phytoremediate the different heavy metals. L. peruviana had the highest concentration and BAFs for the different heavy metals, suggesting it as the best candidate for cleaning these metals from that environment.

The differences in species bioaccumulation factors confirm the fact that metal uptake by plants is species specific. Oxidation state, heavy metals form and phase [37], plant species inherent control and soil/sediment quality [38] strongly influence their bioavailability. A large number of other factors control metal accumulation and bioavailability in association with soil and climatic conditions. These include plant genotype, the mechanism of uptake (active or passive), transfer processes, sequestration and speciation, type of plant root system and the response of plants to elements in relation to seasonal cycles [39].

Table 3. Bioaccumulation Factor (BAF), Biological Accumulation Coefficient (BAC), Biological Concentration Factor (BCF) and Transfer Factor (TF) of heavy metals from Nange-Buea.

\begin{tabular}{|c|c|c|c|c|c|}
\hline Index & Species & $\mathrm{Cu}$ & $\mathrm{Zn}$ & $\mathrm{Pb}$ & $\mathrm{Cd}$ \\
\hline \multirow{7}{*}{ BAF } & A. barteri & 7.16 & 24.98 & 16.24 & 4.85 \\
\hline & L. peruviana & 22.95 & 33.41 & 21.79 & 7.85 \\
\hline & C. benghalensis & 20.19 & 16.61 & 13.03 & 1.73 \\
\hline & & & & & \\
\hline & P. persicaria & 12.32 & 14.28 & 12.56 & 2.58 \\
\hline & R. nasturtium-aquaticum & 20.56 & 17.70 & 11.60 & 3.10 \\
\hline & V. spiralis & 15.19 & 17.92 & 12.26 & 1.98 \\
\hline \multirow[b]{2}{*}{ BAC } & A. barteri & 4.29 & 13.95 & 8.51 & 3.23 \\
\hline & L. peruviana & 10.11 & 14.73 & 11.39 & 3.85 \\
\hline \multirow{3}{*}{$\mathrm{BCF}$} & A. barteri & 2.87 & 11.02 & 7.73 & 1.62 \\
\hline & & & & & \\
\hline & L. peruviana & 12.84 & 18.67 & 10.40 & 4.00 \\
\hline \multirow{2}{*}{ TF } & A. barteri & 1.49 & 1.27 & 1.10 & 1.99 \\
\hline & L. peruviana & 0.79 & 0.79 & 1.10 & 0.96 \\
\hline
\end{tabular}


$\mathrm{pH}$ and clay particles are important parameters which affect the absorption of heavy metals on sediments. Depending on the nature of heavy metal, a decrease in $\mathrm{pH}$ would increase metal availability, lending it to greater uptake by plants. This could be the possible reason for uptake of the heavy metals by the different species since all the sediment $\mathrm{pH}$ values were in the acidic wing. Increase in soil $\mathrm{pH}$ makes cationic metals less likely to be available to plants unlike anionic metals. This explains the ready availability of the metals in the sediments for uptake because their retention potentials were reduced by acidic conditions.

L. peruviana had the highest $\mathrm{BAC}(\mathrm{Cu}=10.11, \mathrm{Zn}=14.73, \mathrm{~Pb}=11.39, \mathrm{Cd}=$ 3.85) and $\mathrm{BCF}(\mathrm{Cu}=12.84, \mathrm{Zn}=18.67, \mathrm{~Pb}=10.40, \mathrm{Cd}=4.00) . A$ barteri had the highest $\mathrm{TF}(\mathrm{Cu}=1.49, \mathrm{Zn}=1.27, \mathrm{Cd}=1.99)$ except for $\mathrm{Pb}$ where both $A$. barteri and $L$. peruviana each had a TF of 1.10 (Table 3). Although all the BAC values were greater $>1, L$. peruviana was the most efficient in accumulating the four heavy metals.

Phytostabilisation depends on the ability of roots to limit pollutants' mobility and bio-availability in the soils/sediments and this occurs through sorption, precipitation, complexation or metal valence reduction [40]. Species with phytostabilisation potential have BCF $>1$ and TF $<1$. Results of the study showed that $L$. peruviana had phytostabilisation potential for $\mathrm{Cu}, \mathrm{Zn}$ and $\mathrm{Cd}$ meanwhile none of the species phytostabilised $\mathrm{Pb}$.

Environmental remediation can be achieved through different options such as physical, chemical and biological. These options employ different methods including thermal treatment, adsorption, chlorination, chemical extraction, io-exchange, membrane separation, electro kinetics and bioleaching. These processes though successful also have disadvantages such as efficiency, cost and failure during large scale implementation. Phytoremediation is cheap, environmentally friendly and easy to manage as it uses native vegetation, leaving no unwanted residues in the environment.

\section{Conclusion}

Car wash contributed to heavy metal load of the stream. While all the six plants were found to be good accumulators of the heavy metals, Ludwigia peruviana showed remarkable efficiency indicating that the species is a good candidate for cleaning such environments. However, legislation restricting the position of car wash from water bodies and also the discharge of effluent from such facilities will reduce the build up of such heavy metals.

\section{Conflicts of Interest}

The authors declare no conflicts of interest regarding the publication of this paper.

\section{References}

[1] Chambers, P.A., Lacoul, P.M., Murphy, K.J. and Thomaz S.M. (2008) Global Diver- 
sity of Aquatic Macrophytes in Freshwater. Hydrobiolgia, 595, 9-26. https://doi.org/10.1007/s10750-007-9154-6

[2] Howard, J. (2009) Car Wash Pollution and the Numbers to Prove It. Federal Way Mirror Reporter July 30 2009, 2 p.

[3] Shanbehzadeh, S., Dastjerdi, M.V., Hassanzadeh, A. and Kiyanizadeh, T. (2014) Heavy Metals in Water and Sediment: A Case Study of Tembi River. Journal of Environmental and Public Health, 2014, Article ID: 858720. https://doi.org/10.1155/2014/858720

[4] Jaishankar, M., Tseten, T., Anbalagan, N., Mathew, B.B. and Beregowda, N.N. (2014) Toxicity, Mechanism and Health Effects of Some Heavy Metals. Interdisciplinary Toxicology, 7, 60-72. https://doi.org/10.2478/intox-2014-0009

[5] Izah, S.C., Injang, I.R., Angaye, T.C.N. and Okowa, I.P. (2017) A Review of Heavy Metal Concentration and Potential Health Implications of Beverages Consumed in Nigeria. Toxics, 5, 1. https://doi.org/10.3390/toxics5010001

[6] Chibuike, G.U. and Obiora, S.C. (2014) Heavy Metal Polluted Soils: Effect on Plants and Bioremediation Methods. Applied and Environmental Soil Science, 2014, Article ID: 752708. https://doi.org/10.1155/2014/752708

[7] Sood, A., Uniyal, P.L., Prasanna, R. and Ahluwalia, A.S. (2012) Phytoremediation Potential of Aquatic Macrophyte, Azolla. Ambio, 41, 122-137. https://doi.org/10.1007/s13280-011-0159-Z

[8] United States Environmental Protection Agency (US EPA) (2002) The Successful Implementation of the Clean Water Act's Section 319 Nonpoint Source Pollution Programme. US Environmental Protection Agency of Water, Washington DC.

[9] Zhou, Q., Zhang, J., Fu, J., Shi, J. and Jiang, G. (2008) Biomonitoring: An Appealing Tool for Assessment of Metal Pollution in the Aquatic Ecosystem. Analytica Chimica Acta, 606, 135-150. https://doi.org/10.1016/j.aca.2007.11.018

[10] Gomes, M.A.C., Hauser-Davis, R.A., Souza, A.N. and Vitória, A.P. (2016) Metal Phytoremediation: General Strategies, Genetically Modified Plants and Applications in Metal Nanoparticle Contamination. Ecotoxicology and Environmental Safety, 134, 133-147. https://doi.org/10.1016/j.ecoenv.2016.08.024

[11] Kio, P.R.O. and Ola-Adams, B.A. (1987) Economic Importance of Aquatic Macrophytes. In: Iloba, C., Ed., Ecological Implications in the Development of Water Bodies in Nigeria. Proceedings of Ecological Society of Nigeria, ECOSON, New Bussa, 54-66.

[12] Fonkou, T., Agendia, P. and Kengne, I. (2005) Heavy Metal Concentrations in Some Biotic and Abiotic Components of the Olezoa Wetland Complex Yaoundé-Cameroon, West Africa. Water Quality Research Journal of Canada, 40, 457-461. https://doi.org/10.2166/wqri.2005.048

[13] Duman, F., Leblebici, Z. and Aksoy, A. (2009) Growth and Bioaccumulation Characteristics of Watercress (Nasturtium officinale R.BR.) Exposed to Cadmium, Cobalt and Chromium. Chemical Specialization and Bioavailability, 21, 257-265. https://doi.org/10.3184/095422909X12578511366924

[14] Kara, Y. (2010) Bioaccumulation of Nickel by Aquatic Macrophytes. Desalination and Water Treatment, 19, 325-328. https://doi.org/10.5004/dwt.2010.1969

[15] Okayi, R.G., Chokom, A.A. and Angera, S.M. (2011) Aquatic Macrophytes and Water Quality Parameters of Selected Flood Plains and River Benue, Makurdi, Benue State, Nigeria. Journal of Animal and Plant Science, 12, 1653-1662.

[16] Fawzy, M.A., El-Sayed, B.N., El-Khatib, A. and Abo-El-Kassem, A. (2011) Heavy 
Metal Biomonitoring and Phytoremediation Potentialities of Aquatic Macrophytes in River Nile. Environmental Monitoring and Assessment, 184, 1753-1771. https://doi.org/10.1007/s10661-011-2076-9

[17] Roy, S., Kumar, S. and Biswas, J.K. (2014) Nutrient Removal from Waste Water by Macrophytes-An Eco-Friendly Approach to Waste Water Treatment and Management. Energy and Environment Research, 4, 55.

https://doi.org/10.5539/eer.v4n2p55

[18] Lum, A.F., Ngwa, E.S.A., Chikoye, D. and Suh, C.E. (2014) Phytoremediation Potential of Weeds in Heavy Metal Contaminated Soils of the Bassa Industrial Zone of Douala, Cameroon. International Journal of Phytoremediation, 16, 302-319. https://doi.org/10.1080/15226514.2013.773282

[19] Waziri, M., Abdullahi, U., Audu, A.A. and Kalimullah (2016) Phytoremediation Potentials of Selected Plants in Industrially Contaminated Soils. International Journal of Environmental Science and Development, 7, 757-762. https://doi.org/10.18178/ijesd.2016.7.10.875

[20] Yabanli, M., Yozukmaz, A. and Sel, F. (2014) Heavy Metal Accumulation in the Leaves, Stem and Root of the Invasive Submerged Macrophyte Myriophyllum spicatum L. (Haloragaceae): An Example of Kadın Creek (Mugla Turkey). Brazilian Archives of Biology and Technology, 57, 434-440. https://doi.org/10.1590/S1516-8913201401962

[21] Basile, A., Sorbo, S., Conte, B., Cobianchi, R.C., Trinchella, F., Capasso, C. and Carginale, V. (2012) Toxicity, Accumulation and Removal of Heavy Metals by Three Aquatic Macrophytes. International Journal of Phytoremediation, 14, 374-387. https://doi.org/10.1080/15226514.2011.620653

[22] Sekabira, K., Oryem-Origa, H., Mutumba, G., Kakudidi, E. and Basamba, T.A. (2011) Heavy Metal Phytoremediation by Commelina benghalensis (L) and Cynodon dactylon (L) Growing in Urban Stream Sediments. International Journal of Plant Physiology and Biochemistry, 3, 133-142.

[23] Abagale, F.K., Osei, R.A., Ojediran, J.O. and Abdul-Ganiyu, S. (2013) Heavy Metal Concentration in Wastewater from Car Washing Bays Used for Agriculture in the Tamale Metropolis, Ghana. International Journal of Current Research, 5, 1571-1576.

[24] Rai, R., Sharma, S., Gurung, D.B. and Sitaula, B.K. (2019) Heavy Metal Contamination in Sediments from Vehicle Washing: A Case Study of Olarong Chhu Stream and Paa Chhu River, Bhutan. International Journal of Environmental Sciences, 76, 66-83. https://doi.org/10.1080/00207233.2018.1525851

[25] Rai, R., Sharma, S., Gurung, D.B., Sitaula, B.K. and Shah, R.D.T. (2020) Assessing the Impacts of Vehicle Wash Wastewater on Surface Water Quality through Physico-Chemical and Benthic Macro-Invertebrates Analyses. Water Science. https://doi.org/10.1080/11104929.2020.1731136

[26] Fonge, B.A., Tabot, P.T., Mange, C.A. and Mumbang, C. (2015) Phytoplankton Community Structure and Physico-Chemical Characteristics of Streams Flowing through an Agro-Plantation Complex in Tiko, Cameroon. Journal of Ecology and the Natural Environment, 7, 170-179. https://doi.org/10.5897/JENE2015.0515

[27] Anyinkeng, N., Afui, M.M., Tening, A.S. and Awah, C.C. (2016) Phytoplankton Diversity and Abundance in Water Bodies as Affected by Anthropogenic Activities within the Buea Municipality, Cameroon. Journal of Ecology and the Natural Environment, 8, 99-114. https://doi.org/10.5897/JENE2016.0566

[28] Ndemanou, F.L. (2017) Potential Effects of Carwash Facilities on Surface Water Bodies, the Case of Selected Areas in Fako Division, South West Region of Cameroon. 
An M.Sc. Thesis, The Department of Development Studies of the Pan African Institute for Development West Africa (PAID_WA), Buea, 90 p.

[29] Folifac, F., Lifongo, L., Nkeng, G. and Gaskin, S. (2009) Municipal Drinking Water Source Protection in Low Income Countries: Case of Buea Municipality Cameroon. Journal of Ecology and Natural Environment, 1, 73-84.

[30] Suh, C.E., Sparks, R.S.J., Fitton, J.G., Ayonghe, S.N., Annen, C., Nana, R. and Luckman, A. (2003) The 1999 and 2000 Eruptions of Mount Cameroon: Eruption Behavior and Petrochemistry of Lava. Bulletin of Volcanology, 65, 267-281. https://doi.org/10.1007/s00445-002-0257-7

[31] National Institute of Statistics, Cameroon, 2010. http://cameroon.opendataforafrica.org

[32] Anyinkeng, N., Mih, M.A. and Tening, A.S. (2020) Diversity and Abundance of Macrophytes of Streams under Different Anthropogenic Influences in the Buea Municipality, Southwestern Cameroon. World Journal of Advanced Research and Reviews, 5, 1-15. https://doi.org/10.30574/wjarr.2020.5.1.0112

[33] Metcalf and Eddy Inc. (2003) Water Reuse: Issues Technologies, and Applications. New York.

[34] Genchi, G., Sinicropi, M.S., Lauria, G., Carocci, A. and Catalano, A. (2020) The Effects of Cadmium Toxicity. International Journal of Environmental Research and Public Health, 17, 3782. https://doi.org/10.3390/ijerph17113782

[35] Linnik, P.M. and Zubenko, I.B. (2000) Role of Bottom Sediments in the Secondary Pollution of Aquatic Environments by Heavy-Metal Compounds. Lakes Reservoirs and Resources Management, 5, 11-21. https://doi.org/10.1046/j.1440-1770.2000.00094.x

[36] Mellem, J., Baijanth, H. and Odhav, B. (2009) Translocation and Accumulation of $\mathrm{Cr}, \mathrm{Hg}, \mathrm{As}, \mathrm{Pb}, \mathrm{Cu}$ and $\mathrm{Ni}$ by Amaranthus dubius (Amaranthaceae) from Contaminated Sites. Journal of Environmental Science and Health, 44, 568-575. https://doi.org/10.1080/10934520902784583

[37] Mahmood, A. and Malik, R.N. (2014) Human Health Risk Assessment of Heavy Metals via Consumption of Contaminated Vegetables Collected from Different Irrigation Sources in Lahore, Pakistan. Arabian Journal of Chemistry, 7, 91-99. https://doi.org/10.1016/j.arabjc.2013.07.002

[38] Chunilall, V., Kindness, A. and Jonnalagadda, S.B. (2005) Heavy Metal Uptake by Two Edible Amaranthus Herbs Grown on Soils Contaminated with Lead, Mercury, Cadmium and Nickel. Journal of Environmental Science and Health, 40, 375-384. https://doi.org/10.1081/PFC-200045573

[39] Kabata-Pendias, A. and Pendias, H. (1984) Trace Elements in Soils and Plants. CRC Press, Boca Raton, 505 p.

[40] Ghosh, M. and Singh, S.P. (2005) A Review on Phytoremediation of Heavy Metals and Utilization of Its By-Products. Asian Journal of Energy and Environment, 6, 4117-4121. 